\title{
A Novel Approach for Accelerated Fabrication of Calcium Hydroxyapatite Thin Films
}

\author{
Pranas USINSKAS ${ }^{1}{ }^{*}$, Živilė STANKEVIČIŪTE் ${ }^{1}$, Gediminas NIAURA $^{2}$, \\ Justinas ČEPONKUS ${ }^{2}$, Aivaras KAREIVA ${ }^{1}$
}

${ }^{1}$ Institute of Chemistry, Vilnius University, Naugarduko 24, LT-03225, Vilnius, Lithuania

${ }^{2}$ Institute of Chemical Physics, Vilnius University, Sauletekio Ave. 9-3, LT-10222, Vilnius, Lithuania

crossref http://dx.doi.org/10.5755/j01.ms.25.4.21251

\section{Received 16 July 2018; accepted 22 October 2018}

\begin{abstract}
In this study we demonstrate, that sol-gel route is suitable to quicker obtain calcium hydroxyapatite $\left(\mathrm{Ca}_{10}\left(\mathrm{PO}_{4}\right)_{6}(\mathrm{OH})_{2}\right.$, CHAp) coatings on crystalline $\mathrm{Si}$ substrate by modified dip-coating technique. The substrate was dip-coated by precursor and dried for 10 minutes at $200{ }^{\circ} \mathrm{C}$ with following cooling using the heating block for 110 min and annealing at $650{ }^{\circ} \mathrm{C}$. Ethylendiamintetraacetic acid and 1,2-ethandiol, and triethanolamine and polyvinyl alcohol were used as complexing agents and as gel network forming agents, respectively. The obtained coatings were characterized by X-ray diffraction (XRD) analysis, scanning electron microscopy (SEM), FTIR spectroscopy and contact angle measurements (CAM).

Keywords: hydroxyapatite, sol-gel, dip-coating, thin film.
\end{abstract}

\section{INTRODUCTION}

Engineering of biomaterials is a growing field that focuses on the development of materials to replace or augment human tissues [1]. Orthopedic and dental implants are medical devices manufactured to replace a missing joint or bone or to support a damaged bone [2] The medical implants are mainly fabricated using stainless steel and titanium alloys [1,3]. As the metal implants should stay in the human body for a long time, they should not have drawbacks like corrosion or dissolution and toxic ion release.

Many different techniques are being used to synthesize Calcium Hydroxyapatite (CHAp) coatings on the substrate [4]. Plasma spraying is the only one approved by the Food and Drug Administration (FDA) [5]. This method is being criticized because of its expensive equipment, use of high temperatures, which may cause degradation on CHAp and difficulty in controlling coating quality and adhesion [6]. Dip-coating, combined with sol-gel processing in an inexpensive and simple process, that can be carried out with simple equipment. This method allows to mass produce coating on various size and shape substrates and the parameters can be controlled through sol-gel concentration, withdrawal speed and annealing temperatures. Also, high purity and homogeneity can be achieved. On the other hand, annealing temperatures are usually high and coating is brittle [7-9].

In this study we combined dip-coating with sol-gel processing to produce quicker CHAp films on silica substrate. Drying step was introduced into dip-coating process that made this process less time consuming.

\footnotetext{
* Corresponding author. Tel.: +370-6-0100440;

E-mail address: pranas_usinskas@yahoo.com (P. Usinskas)
}

\section{EXPERIMENTAL DETAILS}

To prepare CHAp films, calcium acetate monohydrate was used as calcium source. To the aqueous solution of $\mathrm{Ca}\left(\mathrm{CH}_{3} \mathrm{COO}\right)_{2}$ the 1,2-ethandiol was added. The obtained mixture was stirred for $30 \mathrm{~min}$ at $65^{\circ} \mathrm{C}$. Then ethylenediaminetetraacetic acid was added, and after 15 min triethanolamine (TEA) was slowly added. The solution was stirred for $10 \mathrm{~h}$. Then diluted orthophosphoric acid was added $(\mathrm{Ca} / \mathrm{P}$ ratio was 1.67$)$. Finally, this solution was mixed by ratio 5:3 with PVA dissolved in distilled water $[10,11]$. All crystalline Si substrates were cleaned in an ultrasonic bath with acetone, ethanol and distilled water sequentially. One dip-coating cycle consisted of dipping the substrate and retrieving it, drying for $10 \mathrm{~min}$ at $200{ }^{\circ} \mathrm{C}$ in dip-coater dryer and leaving for $110 \mathrm{~min}$. The procedure was repeated 5 times. After that, samples were heated at $650{ }^{\circ} \mathrm{C}$ for $5 \mathrm{~h}$ using the heating rate of $1{ }^{\circ} \mathrm{C} / \mathrm{min}$. The samples were cooled to the room temperature within the furnace. The formation of coatings on silicon substrate was performed using a dip-coater (Holmarc HO-TH-02B). The dipping rate of substrate was $85 \mathrm{~mm} / \mathrm{min}$ and lifting rate was $40 \mathrm{~mm} / \mathrm{min}$. The substrate was left in the gel solution for $20 \mathrm{~s}$.

The coatings were characterized by X-ray diffraction (XRD, Rigaku MiniFlex II) analysis, scanning electron microscopy (SEM, Hitachi SU 70) and contact angle measurements (KSV Instrument CAM 100). FTIR spectra were recorded in transmission mode by using FTIR spectrometer ALPHA (Bruker, Inc.), equipped with a room temperature detector DLATGS. Spectra were acquired from 100 interferogram scans with $2 \mathrm{~cm}^{-1}$ resolution.

Blank Si substrate after 6 cycles (without coating) was used as a reference sample. 


\section{RESULTS AND DISCUSSION}

The XRD results of CHAp coatings obtained by accelerated procedure are presented in Fig. 1. The XRD patterns of CHAp films on silica substrate show the formation of CHAp phase already after 1 coating cycle (5 dips).

SEM micrographs of the CHAp coatings are presented in Fig. 2. As seen, a smooth homogenous surface with small grains is obtained after 1 coating cycle. After 3 coating cycles, the surface is rougher, with bigger grains and few cracks. This might be caused by thermal expansion mismatch between the coating and the substrate. This more perfect microstructe could be obtained by controlling the cooling procedure. The final sample, obtained after 6 coating cycles contains the biggest grains due to the increased number of annealing procedures. The SEM results are in a good agreement with the results of contact angle measurements. After the initial coating, the contact angle increased from $67^{\circ}$ (blank sample) to $85^{\circ}$. With the increasing number of coating cycles, the contact angle decreased due to the existence of cracks on the surface and higher porosity.

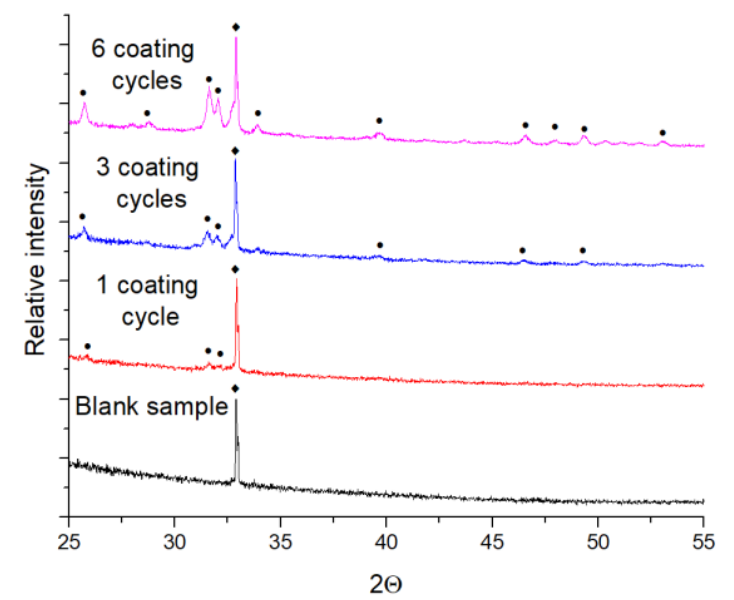

Fig. 1. XRD patterns of CHAp films on silica substrate. Diffraction peaks: •- $\left(\mathrm{Ca}_{10}\left(\mathrm{PO}_{4}\right)_{6}(\mathrm{OH})_{2}(\mathrm{PDF}: 74-0566)\right.$; $\checkmark-\mathrm{Si}$

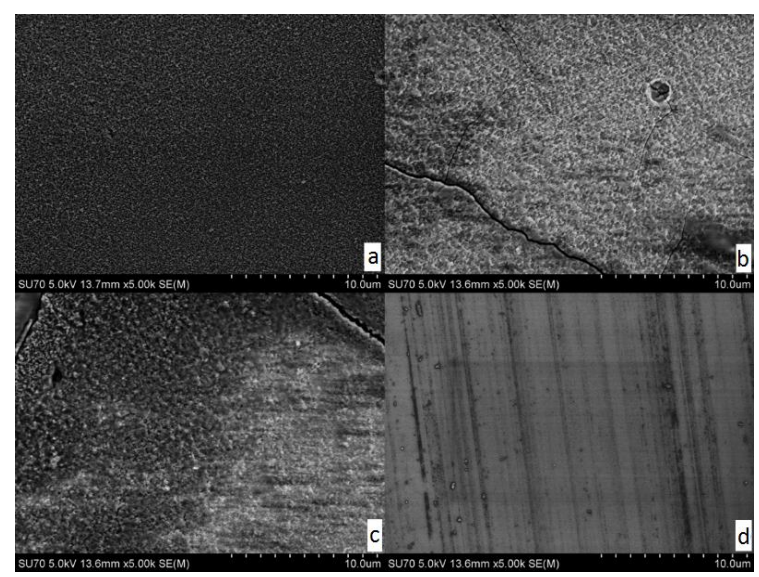

Fig. 2. SEM micrographs of CHAp coatings obtained on silica: $a-1, b-3 ; c-6$ coating cycles; $d-$ blank sample

Fourier transform infrared (FTIR) spectroscopy in transmission mode revealed that free $\mathrm{PO}_{4}{ }^{3-}$ ion belongs to tetrahedral $\left(T_{\mathrm{d}}\right)$ symmetry and its vibrational spectrum consists from four modes; Raman-active totally symmetric stretching $v_{1}\left(A_{1}\right)$, Raman-active double degenerate symmetric deformation $v_{2}(E)$, both infrared- and Ramanactive triply degenerate asymmetric stretching $v_{3}\left(F_{2}\right)$, and both infrared- and Raman-active triply degenerate asymmetric deformation $v_{4} \quad\left(F_{2}\right)$ vibrational modes [12-15]. Fig. 3 compares FTIR spectra of different CHAp layers on Si substrate. Peak positions and assignments of the bands are listed in Table 1. Peak positions of the $\mathrm{PO}_{4}{ }^{3-}$ coincide well with hydroxyapatite structure [16-18]. In the high frequency region, the sharp band due to $\mathrm{O}-\mathrm{H}$ stretching vibrations of $\mathrm{OH}^{-}$ion is visible at $3571 \mathrm{~cm}^{-1}$; thus confirming presence of the hydroxyapatite crystal lattice. The width of $v(\mathrm{OH})$ band determined as full width at half maximum (FWHM) was found to be $15.5 \mathrm{~cm}^{-1}$ for 6 cycles sample. This value is slightly large comparing with previously reported values for crystalline hydroxyapatite $\left(6-12 \mathrm{~cm}^{-1}\right)$ [19]; however, is considerable lower comparing with calcium hydroxyapatite film on $\mathrm{Si}_{3} \mathrm{~N}_{4}$ substrate $\left(70.3 \mathrm{~cm}^{-1}\right)$ [20].

The relative amount of carbonate ions was evaluated by analysis of integrated intensity ratios $\mathrm{A}\left(\mathrm{CO}_{3}{ }^{2-}\right) / \mathrm{A}\left(\mathrm{PO}_{4}{ }^{3-}\right)$ (Table 1). One can see that relative amount of carbonate slightly increases with decreasing number of deposited layers. The relative amount of hydroxyl ion remains similar for all studied samples. Importantly, the hydroxyapatite structure is preserved even for very thin ( 1 cycle -5 dips) coating on $\mathrm{Si}$, as clearly visible from the presence of $v(\mathrm{OH})$ peak near $3570 \mathrm{~cm}^{-1}$ (Fig. 3).
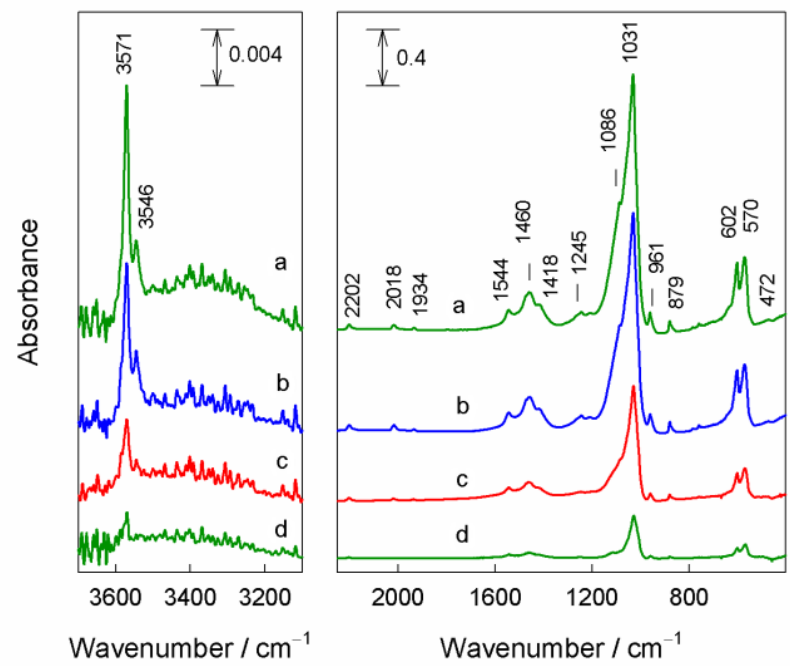

Fig. 3. FTIR absorbance spectra of annealed $\left(650^{\circ} \mathrm{C}, 5 \mathrm{~h}\right) \mathrm{CHAp}$ films on $\mathrm{Si}$ substrate: $\mathrm{a}-6$ cycles, $\mathrm{b}-5$ cycles; $\mathrm{c}-3$ cycles; $d-1$ cycle

\section{CONCLUSIONS}

Calcium hydroxyapatite (CHAp, $\left.\mathrm{Ca}_{10}\left(\mathrm{PO}_{4}\right)_{6}(\mathrm{OH})_{2}\right)$ thin layers were fabricated from $\mathrm{Ca}-\mathrm{P}-\mathrm{O}$ sol-gel solution on silicon ( $\mathrm{Si}$ ) substrate using improved dip-coating method. This suggested technique allowed to achieve desired results 4 times faster in comparison with previously suggested processing. XRD results confirmed the formation of CHAp as single phase after annealing of coatings in air atmosphere at $650{ }^{\circ} \mathrm{C}$ for $5 \mathrm{~h}$. 
Table 1. Infrared wavenumbers $\left[\mathrm{cm}^{-1}\right]$ of CHAp films on Si substrate

\begin{tabular}{|c|c|c|c|c|c|}
\hline $\begin{array}{l}\text { Mode, molecular } \\
\text { group }\end{array}$ & 6 cycles & 5 cycles & 3 cycles & 1 cycle & $\begin{array}{l}\text { Mode, molecular } \\
\text { group }\end{array}$ \\
\hline$v_{1}\left(\mathrm{~A}_{1}\right), \mathrm{PO}_{4}{ }^{3-}$ & $961.3 \mathrm{~m}$ & $961.2 \mathrm{~m}$ & $959.8 \mathrm{~m}$ & $958.8 \mathrm{~m}$ & $961.3 \mathrm{~m}$ \\
\hline$v_{2}(\mathrm{E}), \mathrm{PO}_{4}{ }^{3-}$ & $473 \mathrm{vw}$ & $473 \mathrm{vw}$ & n.o. & n.o. & $473 \mathrm{vw}$ \\
\hline$v_{3}\left(F_{2}\right), \mathrm{PO}_{4}{ }^{3-}$ & $\begin{array}{l}1031.2 \mathrm{vs} \\
1086 \mathrm{sh}\end{array}$ & $\begin{array}{l}1030.6 \mathrm{vs} \\
1085 \mathrm{sh}\end{array}$ & $\begin{array}{l}1029.0 \mathrm{vs} \\
1084 \mathrm{sh}\end{array}$ & $\begin{array}{l}1028.1 \text { vs } \\
\text { n.o. }\end{array}$ & $\begin{array}{l}1031.2 \mathrm{vs} \\
1086 \mathrm{sh}\end{array}$ \\
\hline$v_{4}\left(\mathrm{~F}_{2}\right), \mathrm{PO}_{4}{ }^{3-}$ & $\begin{array}{l}570.4 \mathrm{~s} \\
601.8 \mathrm{~s} \\
\end{array}$ & $\begin{array}{l}570.8 \mathrm{~s} \\
602.2 \mathrm{~s} \\
\end{array}$ & $\begin{array}{l}569.2 \mathrm{~s} \\
601.1 \mathrm{~s} \\
\end{array}$ & $\begin{array}{l}567.8 \mathrm{~s} \\
600.6 \mathrm{~s}\end{array}$ & $\begin{array}{l}570.4 \mathrm{~s} \\
601.8 \mathrm{~s} \\
\end{array}$ \\
\hline $\operatorname{vas}\left(\mathrm{CO}_{3}\right), \mathrm{CO}_{3}{ }^{2-}$ & $\begin{array}{c}1418 \mathrm{~m}, \mathrm{sh} \\
1459.8 \mathrm{~m} \\
1544.3 \mathrm{~m}\end{array}$ & $\begin{array}{c}1419 \mathrm{~m}, \mathrm{sh} \\
1460.4 \mathrm{~m} \\
1543.9 \mathrm{~m}\end{array}$ & $\begin{array}{c}1422 \mathrm{~m}, \mathrm{sh} \\
1460.3 \mathrm{~m} \\
1543.1 \mathrm{~m}\end{array}$ & $\begin{array}{c}1420 \mathrm{~m}, \mathrm{sh} \\
1459.0 \mathrm{~m} \\
1541.1 \mathrm{~m}\end{array}$ & $\begin{array}{c}1418 \mathrm{~m}, \mathrm{sh} \\
1459.8 \mathrm{~m} \\
1544.3 \mathrm{~m}\end{array}$ \\
\hline$\gamma\left(\mathrm{CO}_{3}\right), \mathrm{CO}_{3}{ }^{2-}$ & $879.4 \mathrm{~m}$ & $879.4 \mathrm{~m}$ & $879.6 \mathrm{~m}$ & $879.5 \mathrm{~m}$ & $879.4 \mathrm{~m}$ \\
\hline $\begin{array}{l}\text { Overtones/combination } \\
\text { modes, } \mathrm{PO}_{4}{ }^{3-}, \mathrm{HPO}_{4}{ }^{2-}\end{array}$ & $\begin{array}{l}1933,9 \mathrm{w} \\
2017.5 \mathrm{w} \\
2202.2 \mathrm{w}\end{array}$ & $\begin{array}{l}1934.2 \mathrm{w} \\
2017.0 \mathrm{w} \\
2202.0 \mathrm{w}\end{array}$ & $\begin{array}{l}1935.9 \mathrm{w} \\
2018.2 \mathrm{w} \\
2202.7 \mathrm{w}\end{array}$ & $\begin{array}{l}1936.7 \mathrm{w} \\
2017.0 \mathrm{~m} \\
2202.3 \mathrm{~m}\end{array}$ & $\begin{array}{l}1933,9 \mathrm{w} \\
2017.5 \mathrm{w} \\
2202.2 \mathrm{w}\end{array}$ \\
\hline$v(\mathrm{OH}) \mathrm{OH}^{-}$ & $\begin{array}{l}3545.6 \mathrm{vw} \\
3570.8 \mathrm{w}\end{array}$ & $\begin{array}{l}3545.1 \mathrm{vw} \\
3570.4 \mathrm{w}\end{array}$ & $\begin{array}{l}3544.7 \mathrm{vw} \\
3570.3 \mathrm{w}\end{array}$ & $\begin{array}{c}\text { n.o. } \\
3570.0 \mathrm{w}\end{array}$ & $\begin{array}{c}3545.6 \mathrm{vw} \\
3570.8 \mathrm{w}\end{array}$ \\
\hline$v_{1}\left(\mathrm{~A}_{1}\right), \mathrm{PO}_{4}{ }^{3-}$ & $961.3 \mathrm{~m}$ & $961.2 \mathrm{~m}$ & $959.8 \mathrm{~m}$ & $958.8 \mathrm{~m}$ & $961.3 \mathrm{~m}$ \\
\hline
\end{tabular}

The spectroscopic data also indicated the presence of ordered crystalline structure of hydroxyapatite film. SEM micrographs of the CHAp surfaces revealed the formation of smooth and homogenous coatings with small grains. The SEM results were in a good agreement with the results of contact angle measurements.

\section{Acknowledgments}

This work was supported by a grant SEMAT (No. SEN-02/2016) of National Research Programme „Healthy ageing" from the Research Council of Lithuania.

\section{REFERENCES}

1. Paital, S.R., Dahotre, N.B. Calcium Phosphate Coatings for Bio-implant Applications: Materials, Performance Factors, and Methodologies Materials Science and Engineering: R: Reports 66 2009: pp. 1-70.

https://doi.org/10.1016/j.mser.2009.05.001

2. Skwarek, E., Janusz, W., Sternik, D. The Influence of the Hydroxyapatite Synthesis Method on the Electrochemical, Surface and Adsorption Properties of Hydroxyapatite Adsorption Science \& Technology $35(5-6)$ 2017: pp. $507-518$. https://doi.org/10.1177/0263617417698966

3. Geuli, O., Metoki, N., Eliaz, N., $\quad$ Mandler, D. Electrochemically Driven Hydroxyapatite Nanoparticles Coating of Medical Implants Advanced Functional Materials 26 2016: pp. 8003-8010. https://doi.org/10.1002/adfm.201603575

4. Huang, Y., Zhang, X., Zhao, R., Mao, H., Yan, Y., Pang, X. Antibacterial Efficacy, Corrosion Resistance, and Cytotoxicity Studies of Copper-Substituted Carbonated Hydroxyapatite Coating on Titanium Substrate Journal of Materials Science 50 2015: pp. 1688-1700. http://dx.doi.org/10.1007/s10853-014-8730-1

5. Mohseni, E., Zalnezhad, E., Bushroa, A.R. Comparative Investigation on the Adhesion of Hydroxyapatite Coating on
Ti-6Al-4V Implant: A Review Paper International Journal of Adhesion and Adhesives 48 2014: pp. 238-257. https://doi.org/10.1016/j.ijadhadh.2013.09.030

6. Shamray, V.F., Sirotinkin, V.P., Smirnov, I.V., Kalita, V.I., Fedotov, A.Y., Barinov, S.M., Komlev, V.S. Structure of the Hydroxyapatite Plasma-Sprayed Coatings Deposited on Pre-heated Titanium Substrates Ceramics International 43 2017: pp. 9105-9109. https://doi.org/10.1016/j.ceramint.2017.04.057

7. Valle, G.G., Hammer, P., Pulcinelli, S.H., Santilli, C.V. Transparent and Conductive Zno:Al Thin Films Prepared By Sol-Gel Dip-Coating Journal of the European Ceramic Society 24 2004: pp. 1009-1013. https://doi.org/10.1016/S0955-2219(03)00597-1

8. Song, Y.W., Shan, D.Y., Han, E.H. Electrodeposition of Hydroxyapatite Coating on AZ91D Magnesium Alloy gor Biomaterial Application Materials Letters 62 2008: pp. 3276-3279. https://doi.org/10.1016/j.matlet.2008.02.048

9. Catauro, M., Papale, F., Bollino, F. Characterization and Biological Properties of Tio2/PCL Hybrid Layers Prepared Via Sol-Gel Dip Coating for Surface Modification of Titanium Implants Journal of Non-Crystalline Solids 415 2015: pp. $9-15$. https://doi.org/10.1016/j.jnoncrysol.2014.12.008

10. Usinskas, P., $\quad$ Stankeviciute, Z., Niaura, G., Maminskas, J., Juodzbalys, G., Kareiva, A. Sol-gel Processing of Calcium Hydroxyapatite Thin Films on Silicon Nitride $\left(\mathrm{Si}_{3} \mathrm{~N}_{4}\right)$ Substrate Journal of Sol-Gel Science and Technology 83 2017: pp. 268-274. http://dx.doi.org/10.1007/s10971-017-4431-y

11. Usinskas, $P$., $\quad$ Stankeviciute, $Z$., $\quad$ Beganskienè, A., Kareiva, A. Sol-gel Derived Porous and Hydrophilic Calcium Hydroxyapatite Coating on Modified Titanium Substrate Surface and Coatings Technology 307 2016: pp. $935-940$. https://doi.org/10.1016/j.surfcoat.2016.10.032

12. Jastrzębski, W., Sitarz, M., Rokita, M., Bułat, K. Infrared Spectroscopy of Different Phosphates Structures 
Spectrochimica Acta Part A: Molecular and Biomolecular Spectroscopy 79 2011: pp. 722-727.

https://doi.org/10.1016/j.saa.2010.08.044

13. Nakamoto, K. Infrared and Raman Spectra of Inorganic and Coordination Compounds, Part A: Theory and Applications in Inorganic Chemistry, Wiley 2008.

https://doi.org/10.1002/0470027320.s4104

14. Niaura, G., Gaigalas, A., Vilker, V.L. Surface-Enhanced Raman Spectroscopy of Phosphate Anions: Adsorption on Silver, Gold, and Copper Electrodes The Journal of Physical Chemistry B 101 (45) 1997: pp. 9250 - 9262, 1997. https://doi.org/10.1021/jp970097k

15. Posset, U., Löcklin, E., Thull, R., Kiefer, W. Vibrational Spectroscopic Study of Tetracalcium Phosphate in Pure Crystalline Form and as a Constituent of a Self-Setting Bone Cement Journal of Biomedical Materials Research 40 (4) 1998: pp. 64-645.

https://doi.org/10.1002/(SICI)1097-

4636(19980615)40:4\%3C640::AID-JBM16\%3E3.0.CO;2-J

16. Karampas, I.A., Kontoyannis, C.G. Characterization of Calcium Phosphates Mixtures Vibrational Spectroscopy 64 2013: pp. 126-133.

https://doi.org/10.1016/j.vibspec.2012.11.003
17. Rehman, I., Bonfield, W. Characterization of Hydroxyapatite and Carbonated Apatite by Photo Acoustic FTIR Spectroscopy Journal of Materials Science: Materials in Medicine 8 1997: pp. 1-4.

18. Frasnelli, M., Cristofaro, F., Sglavo, V.M., Dirè, S., Callone, E., Ceccato, R., Bruni, G., Cornaglia, A.I., Visai, L. Synthesis and Characterization of StrontiumSubstituted Hydroxyapatite Nanoparticles for Bone Regeneration Materials Science and Engineering: $C \quad 71$ 2017: pp. $653-662$. https://doi.org/10.1016/j.msec.2016.10.047

19. Saber-Samandari, S., Alamara, K., Saber-Samandari, S., Gross, K.A. Micro-Raman Spectroscopy Shows how the Coating Process Affects the Characteristics of Hydroxylapatite Acta Biomaterialia 9 2013: pp. $9538-9546$. https://doi.org/10.1016/j.actbio.2013.08.021

20. Arends, J., Davidson, C.L. $\mathrm{HPO}_{4}{ }^{2-}$ Content in Enamel and Artificial Carious Lesions Calcified Tissue Research 18 1975: pp. $65-79$. http://doi.org/10.1007/BF02546227 